University for Business and Technology in Kosovo

UBT Knowledge Center

UBT International Conference

2017 UBT International Conference

Oct 27th, 4:45 PM - 6:15 PM

\title{
Evaluation of the Ereniku river waters in the locations where the Lukac river flows
}

\author{
Faton Maloku \\ University for Business and Technology, faton.maloku@ubt-uni.net \\ Luan Daija \\ Regional WaterCompany, luan_daija@yahoo.com \\ Xhelal Këpuska \\ Business College Prishtina, xhelalkepuska@yahoo.com
}

Follow this and additional works at: https://knowledgecenter.ubt-uni.net/conference

Part of the Bioresource and Agricultural Engineering Commons

\begin{abstract}
Recommended Citation
Maloku, Faton; Daija, Luan; and Këpuska, Xhelal, "Evaluation of the Ereniku river waters in the locations where the Lukac river flows" (2017). UBT International Conference. 138.

https://knowledgecenter.ubt-uni.net/conference/2017/all-events/138

This Event is brought to you for free and open access by the Publication and Journals at UBT Knowledge Center. It has been accepted for inclusion in UBT International Conference by an authorized administrator of UBT Knowledge Center. For more information, please contact knowledge.center@ubt-uni.net.
\end{abstract}




\title{
Evaluation of the Ereniku river waters in the locations where the Lukac river flows
}

\author{
Faton Maloku ${ }^{1}$, Luan Daija ${ }^{2}$, Xhelal Këpuska ${ }^{3}$ \\ ${ }^{1}$ UBT-Institution of Higher Education, \\ 2. Regional Water Company "Radoniqi” Gjakova \\ ${ }^{3}$ Business College Prishtina \\ faton.maloku@ubt-uni.net, luan_daija@yahoo.com,xhelalkepuska@yahoo.com
}

\begin{abstract}
The fate and transport of many anthropogenic pollutants have an impact not only on hydrological cycles, but also on physical-chemical processes. Water resource monitoring will determine the quality of water, identify its depreciation, and help policymakers make decisions that will preserve not only natural areas but also improve quality of life. Therefore the purpose of this paper is to evaluate the physical and chemical parameters of the locations where the river Lukac flows into the Erenik River. Erenik is a River in the western part of Kosovo. The water quality of the Ereniku River depends from anthropogenic activities, mainly from sewage discharges, from agriculture, as well as from various factors that perform their activity in the watershed of the Ereniku River.

The samples were taken from the river in June 2017 in three stations (locations) and were analyzed the physical-chemical parameters such as: Iron, Manganese, Ammonia, Nitrites, Nitrates, Phosphates, Aluminum, spending of potassium permanganate, dissolved oxygen, blur, $\mathrm{pH}$, electrical conductivity, Alkalinity, COD, BOD, N and P inorganic forms, etc. Water samples were analyzed in the physical-chemical laboratory such as: $\mathrm{pH}$ values, conductometry, turbidometry, atomic absorption method, spectrophotometric method and classical chemical analysis methods (volumetric).

Parameters such as $\mathrm{pH}$, temperature, hardness, blur are comparable to the qualities of Mountain Rivers, which are not significantly affected by human activities. The TSS, alkaline and EC values are higher where they show the influence of human activity and sewage, as well as the COD and BOD values show the impact of human activity.
\end{abstract}

Key words: River, Ereniku, parameters, evaluation, human.

\section{Introduction}

Population growth may have a negative impact on natural waters by damaging the quality and quantity of water. In order to mitigate the impact of human societies on natural waters, the implementation of a comprehensive monitoring regime is becoming increasingly important.

$\mathrm{PH}$ monitoring is a typical way of evaluating the health of aquatic ecosystems, bathing waters, irrigation springs, livestock, drinking water sources, discharges and rainwater.PH changes may be indicators of the presence of industrial pollutant, photosynthesis or respiration of algae growing in a pollutant. Most ecosystems are sensitive to $\mathrm{pH}$ changes, so $\mathrm{pH}$ monitoring is included in the environmental laws of most industrialized countries.

Dissolved Oxygen (DO) is essential for all forms of aquatic life, including organisms that decompose pollutants made by human. Other indirect laboratory tests for DO estimation are the biological oxygen demand (BOD) and the chemical oxygen demand (COD). BOD is the amount 
of oxygen needed to biologically decompose a pollutant / impurity while COD is the amount of oxygen directly consumed for the chemical oxidation of a pollutant / impurity. During the eutrophication process, oxygen release and respiration occur, resulting in hypoxia - high concentrations and anoxia - low oxygen concentration. Because of reduced light penetration, the photosynthesis process has been reduced / reduced in some areas of the water system (Burkholder et al, 2007).

Turbidity or Total Solids Suspended / Treated (TSS) is the water-based material that affects the transparency or distribution of light in the water. Artificial sources of TSS include erosion, rippling water flow, industrial discharges, microorganisms and eutrophication. Many species of fish are susceptible to prolonged exposure to TSS and TSS monitoring is an important criterion for assessing water quality.

The Electrical Conductivity (EC) is also the measure of the water quality parameters "Total solids dissolved" (TDS) or salinity. About $0.3 \mathrm{~S} / \mathrm{m}$ is the point at which the health of some fresh water aquatic cultures and organisms will be endangered by salinity.

In the environment, plants and microorganisms convert $\mathrm{N}_{2}$ to different oxidation state / levels where it becomes part of the nitrogen cycle. The main inorganic oxidation state / levels include the ions of: nitrates $\left(\mathrm{NO}_{3}^{-}\right)$, nitrites $\left(\mathrm{NO}_{2}^{-}\right)$, ammonia $\left(\mathrm{NH}_{3}\right)$, and ammonium $\left(\mathrm{NH}_{4}^{-}\right)$. Total nitrogen in natural waters refers to the total amount of organic compounds that contain nitrogen and the various levels of inorganic nitrogen oxidation present in the solution.

Eutrophication has become the main concern of water quality for most freshwater, coastal and transitional waters. (Schindler, 2006; Smith, 1983; Zaldivar et al., 2008).

The nitrification process, as it requires oxygen for its development, is carried in the sediment aerobic part until denitrification develops into depth in the anoxic layers of sediment, where the mode of reduction depends on many factors (carbon content / concentration, types of microorganisms, temperature, etc.) (Kelso et al., 1997).

The calcium-bound phosphate fraction is extremely sensitive to $\mathrm{pH}$ changes and can be completely dissoluble to low $\mathrm{pH}$ values. This fraction slowly precipitates in saline water even at high pH values. (Gomez et al., 1999).

Erenik is a river in the western part of Kosovo. It starts at the altitude of the mountains bordering Albania (Cursed Mountains, 2,500 m altitude), descends to the town of Junik, then flows into a field ground up to the town of Gjakova (with a population of about 100,000). According to the length is shorter watercourse than Lumbardhi i Pejes and Lumbardhi i Deçanit, but by the size of the basin and the flow is distinguished from all the right branches of Drini i Bardhe. It stems from the Gjeravica glacial lake and flows to the Drini i Bradhe in the east to the Terezinj Bridge.

Environmental problems related to nitrogen (loads, solubility, transport and water potential for erosion) derive from human activity and the special pressure of liquid wastes and urban waste of all categories, with environmental management of agriculture, industry, waste and sewage. Erosion, rimsing of synthetic and organic fertilizers (vertical movements) and sedimentation are decisive processes, especially in diffuse pollution of the waters of Erenik.

\section{MATERIAL AND METHODS}

This study is carried with the purpose of assessing the waters of the river Ereniku and those in 3 localities (points) those localities are: 1after sewage without any protection criteria of the city of Gjakova or $50 \mathrm{~m}$ before the tributary or Lukac river flows into which is the locality 2 in the spill of the Erenik river as well as the locality 3 after the flow of the river Lukac to the Ereniku river. This assessment of the physicochemical parameters is done in June 2017 in these three locations with which not so far away from the third localion that will become the sewage plant. Therefore it is clear that the purpose of this study is to provide data on the quality of the waters of the Ereniku River and the discharge of polluted waters into the same river. 
During sampling, care should be taken to ensure that the samples present the actual composition of water. Also, sampling and sampling modes have a great impact on the results of the analyzes. These recommendations come from: World Health Organization, WHO (WHO 1993), USEPA 1983.

Water samples were taken in $500 \mathrm{ml}$ of polyethylene bottle which were previously well cleaned and the sample was stored at $4{ }^{\circ} \mathrm{C}$ in the refrigerator, some parameters are determined at the place of sampling and they are: water temperature, $\mathrm{pH}$ value etc., while other parameters should be carefully transported to the laboratory. For laboratory water analysis we use standard methods as described by the APHA standard. Through the UV Hach Spectrophotometer, the Merck Spectraquant 1500T Turbidimeter, we used titrimetric, conductometric, ph-metric methods.

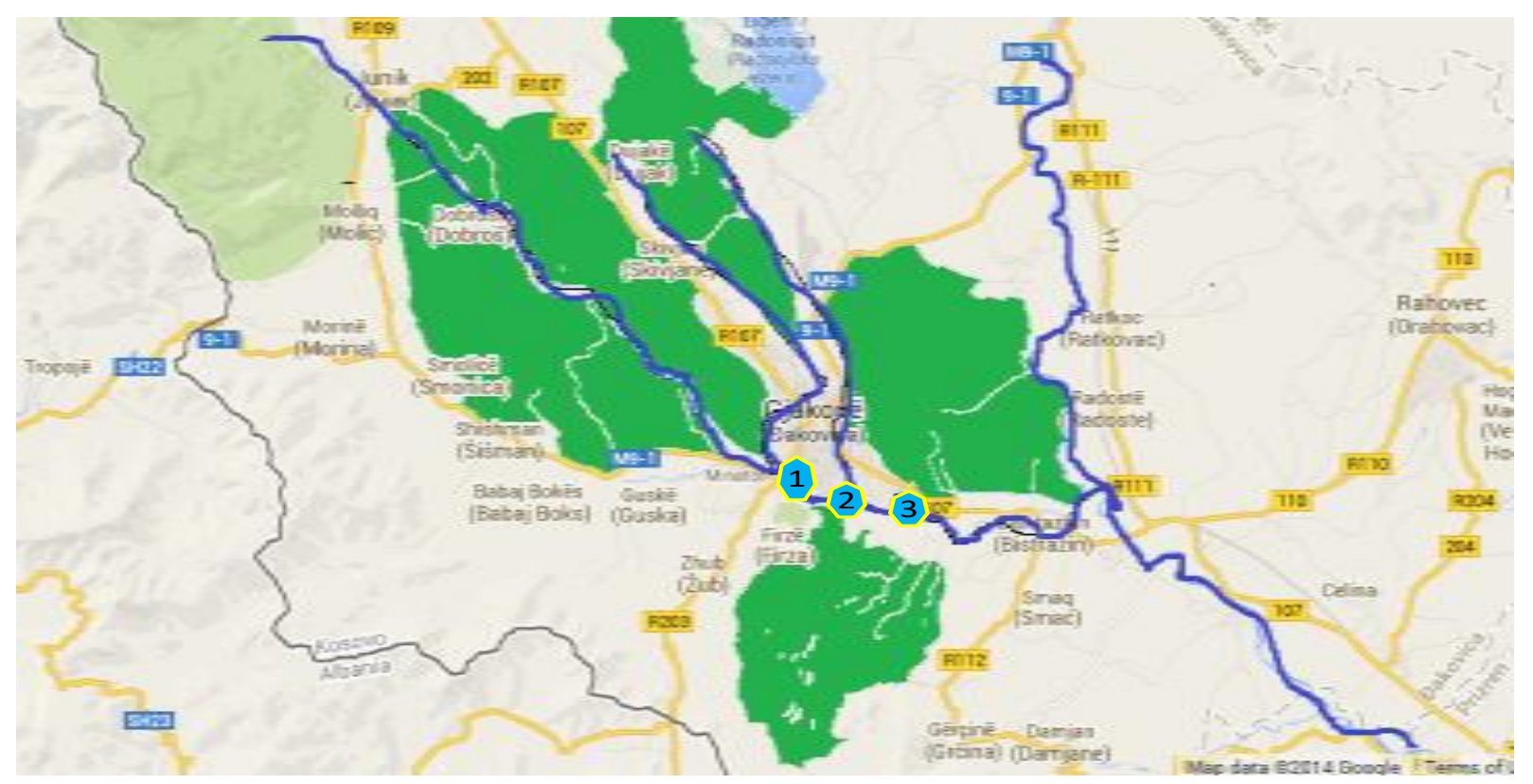

Fig. 1. Locations where samples are taken 
Results of the physicochemical analysis of the Erenik River

\begin{tabular}{|c|c|c|c|c|}
\hline Parameters & Units & $\begin{array}{l}\text { 1-Water after } \\
\text { sewage on the } \\
\text { Erenik river }\end{array}$ & $\begin{array}{l}\text { 2- Water } \\
\text { flowing of the } \\
\text { river Lukac to } \\
\text { the Erenik river }\end{array}$ & $\begin{array}{l}\text { 3- Water of the } \\
\text { Erenik River } \\
\text { after } 50 \mathrm{~m} \text { from } \\
\text { the flow of river } \\
\text { Lukac }\end{array}$ \\
\hline Sampling time & $\mathrm{h}$ & $10: 50$ & $11: 30$ & $12: 00$ \\
\hline Air temperature & ${ }^{0} \mathrm{C}$ & 30.3 & 29.2 & 28,5 \\
\hline Water temperature & ${ }^{0} \mathrm{C}$ & 18 & 19 & 21 \\
\hline Turbidity & NTU & 25.2 & 13.8 & 9.7 \\
\hline $\mathrm{PH}$ - value & - & 9.05 & 8.82 & 8.45 \\
\hline $\begin{array}{l}\text { Consumption of } \\
\mathrm{KMnO}_{4}\end{array}$ & $\mathrm{mg} / \mathrm{dm}^{3}$ & 31.6 & 18.96 & 14.22 \\
\hline $\begin{array}{l}\text { Electrical } \\
\text { Conductivity }\end{array}$ & $\mu \mathrm{s} / \mathrm{cm}$ & 443 & 385 & 359 \\
\hline M-alkaline & $\mathrm{mval} / \mathrm{l}$ & 25.2 & 16.8 & 14.5 \\
\hline Total Hardness & ${ }^{\circ} \mathrm{dH}$ & 8.12 & 7.70 & 7.56 \\
\hline Dry residues & $\mathrm{mg} / \mathrm{dm}^{3}$ & 265.2 & 230.5 & 214.9 \\
\hline (COD) & $\mathrm{mg} / \mathrm{dm}^{3}$ & 8.0 & 4.8 & 3.6 \\
\hline (BOD) & $\mathrm{mg} / \mathrm{dm}^{3}$ & 10.56 & 6.33 & 4.75 \\
\hline Chlorides & $\mathrm{mg} / \mathrm{dm}^{3}$ & 17.72 & 12.76 & 10.63 \\
\hline Dissolved oxygen & $\mathrm{mg} / \mathrm{dm}^{3}$ & 6.7 & 9.7 & 10.2 \\
\hline Iron & $\mathrm{mg} / \mathrm{dm}^{3}$ & 0.89 & 0.37 & 0.24 \\
\hline Manganese & $\mathrm{mg} / \mathrm{dm}^{3}$ & 0.76 & 0.34 & 0.26 \\
\hline Ammonia, $\mathrm{NH}_{3}$ & $\mathrm{mg} / \mathrm{dm}^{3}$ & 1.19 & 0.62 & 0.37 \\
\hline Nitrites, $\mathrm{N}^{-\mathrm{NO}_{2}{ }^{-}}$ & $\mathrm{mg} / \mathrm{dm}^{3}$ & 1.02 & 0.35 & 0.29 \\
\hline Nitrates, $\mathrm{N}^{-\mathrm{NO}_{3}}{ }^{-}$ & $\mathrm{mg} / \mathrm{dm}^{3}$ & 8.70 & 3.80 & 2.80 \\
\hline Sulfates & $\mathrm{mg} / \mathrm{dm}^{3}$ & 66 & 47 & 35 \\
\hline Phosphates & $\mathrm{mg} / \mathrm{dm}^{3}$ & 7.6 & 2.8 & 1.1 \\
\hline
\end{tabular}




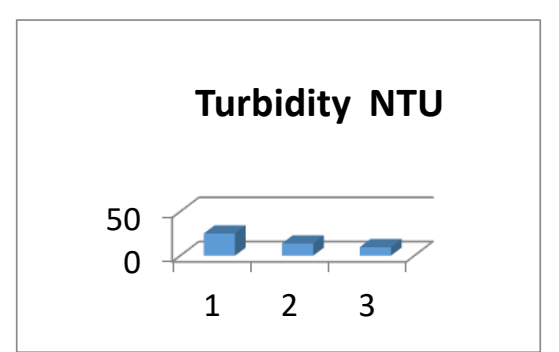

Fig.2.Turbidity of the river Ereniku.

\section{Consumption of \\ $\mathrm{KMnO}_{4} \mathrm{mg} / \mathrm{dm}^{3}$}

50

50
0
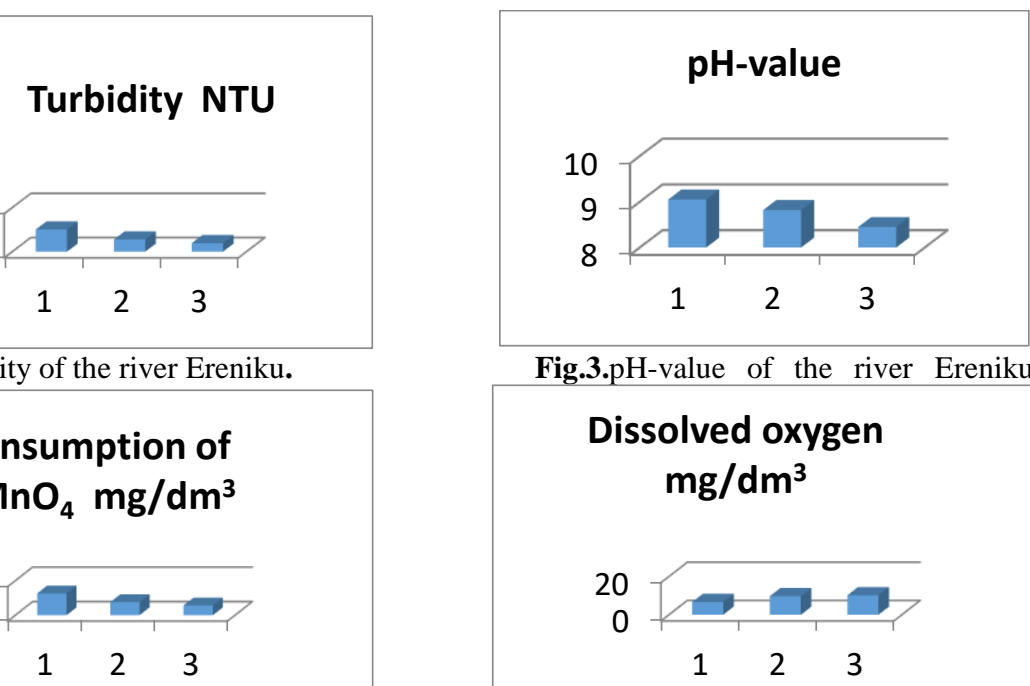

Fig.3.pH-value of the river Ereniku.

\section{Dissolved oxygen \\ $\mathrm{mg} / \mathrm{dm}^{3}$}

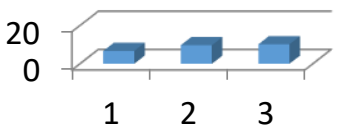

Fig. 5. Dissolved oxygen of the river Ereniku

\section{Ammonia, $\mathrm{NH}_{3} \mathrm{mg} / \mathrm{dm}^{3}$}

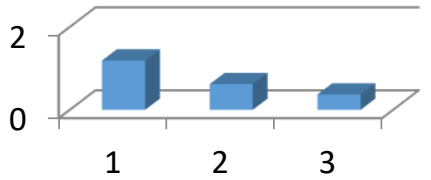

Fig. 8.Ammonia of the river Ereniku.
Manganese $\mathrm{mg} / \mathrm{dm}^{3}$

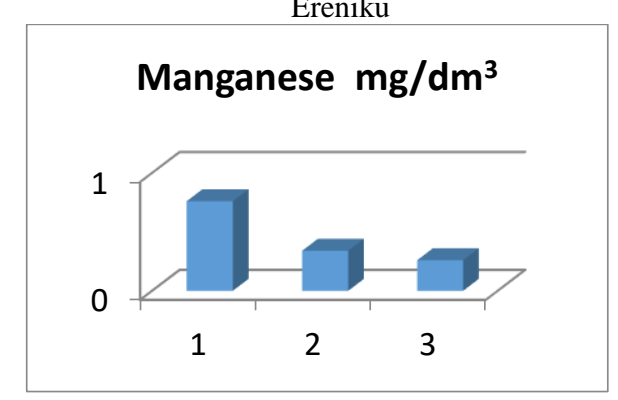

Fig. 7. Manganese of the river Ereniku.

Nitrites, $\mathrm{N}-\mathrm{NO}_{2}^{-} \mathrm{mg} / \mathrm{dm}^{3}$

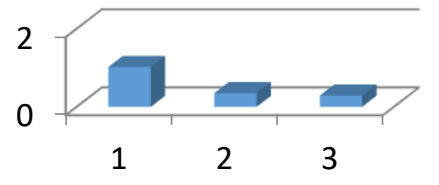

Fig. 9. Nitrites of the river Ereniku.

\section{DISCUSSION}

During the summer 2017, physical and chemical analyzes were carried out, in the three locations of Ereniku river in Gjakova, the results obtained are presented in the table above.

-The temperature of water depends on time, season and place where the samples were taken, they have been different. The lowest water temperature was recorded at the 1 st location $(18 \mathrm{oC})$, the highest water temperature was at 3rd location $(21 \mathrm{oC})$. 
- Regarding turbidity, it varies from the maximum of 25.2 at the point 1 and falls to 9.7 at the point $3 \mathrm{Ntu}$, which means that we have turbiduty increases, because of the growth is the wastewater spill along the Ereniku River.

-The lowest $\mathrm{pH}$ value of water is marked $(8.45 \mathrm{mg} / \mathrm{dm} 3)$ at the $3 \mathrm{rd}$ location. The highest water $\mathrm{pH}$ value was at the $1 \mathrm{st}$ location $(9.05 \mathrm{mg} / \mathrm{dm} 3)$.

-The oxygen dissolved in water that is very important for ecosystems, based on the results, the lowest amount of dissolved oxygen in the water is recorded $(6.7 \mathrm{mg} / \mathrm{dm} 3)$ on site 1 . The highest dissolved oxygen in the water was at the site $3(10.2 \mathrm{mg} / \mathrm{dm} 3)$.

-The highest consumption of $\mathrm{KMnO} 4$ of the water was at the site $1(31.6 \mathrm{mg} / \mathrm{dm} 3)$ while the lowest was at the site $3(14.22 \mathrm{mg} / \mathrm{dm} 3)$.

-Lower ammonia values are also at site $3(0.37 \mathrm{mg} / \mathrm{dm} 3)$, while the highest values are at the site 1 (1.19 mg / dm3).

- The lowest water nitrites are recorded at the site 3 with $(0.29 \mathrm{mg} / \mathrm{dm} 3)$. The highest nitrites of water were at site $1(1.02 \mathrm{mg} / \mathrm{dm} 3)$.

\section{CONCLUSIONS}

The obtained results indicate the quality of the pollution of the Ereniku River as a cause of the discharged quantities of municipal, agricultural, industrial pollutants.

It is recommended by higher State institutions to request accountability from the from relevant Institutions for water protection, in order to:

- to perform water control;

- gradual reduction of pollution, degradation and other activities that pose a high risk to the water environment;

- to build sewage treatment plants, in order to protect the environment, and in particular rivers, respecting water protection according to the European Union Standards.

\section{Literature}

1. .Burkholder, J.M, Tomasko, D.A., Touchette, B.W. (2007).Seagrasses and eutrophication. Journal of Experimental Marine Biology and Ecology 350, 46-72.

2. Schindler, D.W., 2006. Recent advances in the understanding and management of eutrophication. Limnology and Oceanography 51, 356-363.

3. .Smith, V.H., 1983. Low nitrogen to phosphorus ratios favor dominance by bluegreen algae in lake phytoplankton. Science 221, 669-6714 . Z a l d i v a r , J . M ., Cardoso,A.C., Viaroli, P., Newton, A., De Wit, R., I b a n e z, C ., Reizopoulou, S., Somma, F., Razinkovas, A., Basset, A., Holmer, M., Murray, N.,2008. Eutrophication in transitional waters: an overview. Transitional Waters Monographs 2, 1 and 78.

4. .Gomez, C., Durillon, C., Rofes, G., Picot, B. (1999). Phosphate adsorption and release from sediments of Brackish lagoons: $\mathrm{pH}, \mathrm{O} 2$ and loading influence. Wat. Res. 33(10), $2437 \pm 2447$.

5. Kelso, B.H.L., Smith, R.V., Laughlin, R.J., Lennox., S.D. (1997) Dissimilatory Nitrate Reduction in Anaerobic Sediments Leading to River Nitrite Accumulation. Applied and Environmental Microbiology 63,4679-4685.

6. Đuković Đ, Đukić B, Lazić D, Marsević M, (2000) Tehnologija vode,Beograd pp 137-139 